\title{
Determination of the main characteristics of the small waterplane area twin hull ships at the initial stage of design
}

\author{
Oleksandr V. Bondarenko, Assoc. Prof. \\ Anzhela P. Boiko, Assoc. Prof. \\ Iryna R. Seropyan, Engineer second class \\ Admiral Makarov National University of Shipbuilding, Mykolayiv, Ukraine
}

\begin{abstract}
The basic selecting peculiarities of the optimal project characteristics of the small waterplane area twin hull ships compared to conventional ships are considered. The description of the mathematical model and the ship operating model is given. The choice of the optimization method is justified.
\end{abstract}

Keywords: small waterplane area twin hull ship; mathematical model; constraints; objective function; optimization

\section{INTRODUCTION}

Small waterplane area twin hull (SWATH) ships have excellent seaworthiness and are used as pilot, research, passenger, patrol, pleasure yachts due to the peculiarities of their hull form. Because of novelty and lack of its quantity, the design experience of such type of ships is little. Besides, an engineer has to solve a lot of problems that are not inherent for the traditional types of ships when choosing the project characteristics of SWATH ship.

It should also be considered that in case of intense competition in a very short period there must be designed the best ship variant that will be much better than the competing projects. Using the traditional design methods by the original or the variation method gives an opportunity to get the project of SWATH ship that meets the task requirements but doesn't guarantee its high efficiency. The way out of such situation is to move to an optimization design. But the application of the optimization approach requires special knowledge and skills of the engineers, especially in the design of such complex objects as small waterplane area twin hull ships. Therefore, the problem of improving the decisions quality at the initial designing stages of small waterplane area twin hull ships is rather important.

Review of domestic and foreign publications has shown that there are few papers devoted to the application of the optimization approach for the SWATH ship design, for example [1-6]. The analysis of these studies gives grounds for the authors to conclude following issues that require further study:
1. In most models the determine problem is considered that doesn't allow take into account the effect of uncertainty of the initial information on the project efficiency.

2. At the initial design stage the comfort requirements of passengers are hardly set and the reliability factor is ignored.

The aim of the article is to consider the basic selecting peculiarities of the optimal project characteristics of the small waterplane area twin hull ships including the uncertainty of the initial information.

\section{BASIC MODEL}

\section{Design problems}

The basis for the project design is a technical task ( $\mathrm{C}$ vector) containing the SWATH ship specifications set by the owner. Vector $\mathrm{C}$ is as follows:

- required service speed $(\mathrm{kN})$;

- number of passengers;

- endurance (day);

- hull material (steel, aluminum Alloy, glass-reinforced plastic);

- superstructure material (steel, aluminum Alloy, glassreinforced plastic);

- number of struts (single, tandem);

- type of machinery (medium speed diesel, high speed diesel, diesel electric, gas turbine). 
Tab. 1. Design variables and parameters of SWATH ship

\begin{tabular}{|c|c|c|c|c|}
\hline Variable & Symbol & Description & $\mathrm{x}_{\mathrm{i}}^{\min }$ & $\mathrm{x}_{\mathrm{i}}^{\max }$ \\
\hline $\mathrm{x}_{1}$ & $1_{\mathrm{H}}$ & relative length of lower hull $\mathrm{L}_{\mathrm{H}} / \mathrm{D}_{\mathrm{H}}$ & 10 & 20 \\
\hline $\mathrm{x}_{2}$ & $1_{\mathrm{S}}$ & slenderness coefficient of strut $\mathrm{L}_{\mathrm{S}} / \mathrm{t}_{\mathrm{S}}$ & 15 & 35 \\
\hline $\mathrm{x}_{3}$ & $\mathrm{C}_{\mathrm{WPS}}$ & waterplane area strut coefficient & 0.6 & 0.9 \\
\hline $\mathrm{x}_{4}$ & $\mathrm{k}_{\mathrm{W}}$ & relative waterplane area $\mathrm{A}_{\mathrm{WPS}} / \nabla^{2 / 3}$ & 0.5 & 1.5 \\
\hline $\mathrm{x}_{5}$ & $\mathrm{~h}_{\mathrm{c}}$ & ratio of the distance between lower hull center-line to the length of the ship $B_{S} / L_{H}$ & 0.3 & 0.6 \\
\hline $\mathrm{x}_{6}$ & $1_{\mathrm{d}}$ & ratio of the ship draft to the lower hull diameter $\mathrm{d} / \mathrm{D}_{\mathrm{H}}$ & 1.0 & 2.0 \\
\hline $\mathrm{x}_{7}$ & $\mathrm{~b}_{\mathrm{h}}$ & ratio of the lower hull beam to its depth $\mathrm{B}_{\mathrm{H}} / \mathrm{H}_{\mathrm{H}}$ & 1.0 & 2.0 \\
\hline $\mathrm{x}_{8}$ & $\mathrm{C}_{\mathrm{PH}}$ & lower hull prismatic coefficient & 0.5 & 0.9 \\
\hline $\mathrm{X}_{9}$ & $\mathrm{n}_{\mathrm{f}}$ & factor of the lower hull nose shape & 2 & 4 \\
\hline $\mathrm{x}_{10}$ & $\mathrm{n}_{\mathrm{a}}$ & factor of the lower hull tail shape & 2 & 4 \\
\hline $\mathrm{x}_{11}$ & $\mathrm{n}_{\mathrm{h}}$ & factor of the lower hull cross section shape & 2 & 8 \\
\hline $\mathrm{x}_{12}$ & $\mathrm{n}_{\mathrm{s}}$ & strut nose and tail shape factor & 2 & 4 \\
\hline $\mathrm{x}_{13}$ & $1_{\mathrm{NH}}$ & hull nose length to lower hull ratio $\mathrm{L}_{\mathrm{NH}} / \mathrm{L}_{\mathrm{H}}$ & 0.2 & 0.5 \\
\hline $\mathrm{x}_{14}$ & $1_{\mathrm{NS}}$ & strut nose length to strut length ratio $\mathrm{L}_{\mathrm{NS}} / \mathrm{L}_{\mathrm{S}}$ & 0.2 & 0.5 \\
\hline $\mathrm{x}_{15}$ & $\eta_{\mathrm{p}}$ & payload coefficient $\mathrm{W}_{\mathrm{p}} / \Delta$ & 0.05 & 0.30 \\
\hline $\mathrm{x}_{16}$ & $\mathrm{~s}_{-} \mathrm{b}$ & strut setback $\mathrm{S}_{\mathrm{b}} / \mathrm{L}_{\mathrm{H}}$ & -0.1 & 0.1 \\
\hline
\end{tabular}

Let's denote the vector of independent variables through $\mathrm{X}=\left(\mathrm{x}_{1}, \mathrm{x}_{2}, \ldots, \mathrm{x}_{\mathrm{n}}\right)$. The $\mathrm{X}$ vector includes the design variables and parameters of SWATH ship (Table 1).

The optimization problem of SWATH ship at the initial stage of design is formally stated as follows:

Minimize or maximize objective function:

$$
\mathrm{f}(\mathrm{X}, \mathrm{C}) \rightarrow \min (\max )
$$

Subject to the bound constraints:

$$
\mathrm{x}_{\mathrm{i}}^{\min } \leq \mathrm{x}_{\mathrm{i}} \leq \mathrm{x}_{\mathrm{i}}^{\max } ; \mathrm{i}=1, \ldots, \mathrm{n}
$$

and functional constraints:

$$
\mathrm{g}_{\mathrm{j}}(\mathrm{X}) \geq 0 ; \mathrm{i}=1, \ldots, \mathrm{m}
$$

where:

$\mathrm{m} \quad-$ total number of constraints;

$x_{i}^{\text {min }}, x_{i}^{\max }$ - lower and upper bounds on the independent variable (see Table 1);

n $\quad-$ number of independent variables

The functional constraints of the $\mathrm{g}_{\mathrm{j}}(\mathrm{X}) \geq 0$ task include inequalities that define the ship performance requirements. The following constraints include:

- requirements for intact stability (High Speed Craft Code);

- rolling period;

- equality between weight and displacement;

- minimum value of lower hull diameter;

- maximum value of draft;

- maximum value of breadth;

- minimum and maximum values of strut tail length;

- minimum and maximum values of strut tail length;

- minimum and maximum values of lower hull tail length;

- motion sickness indexes (MSI) and etc.

All of these constraints are got on the basis of the analysis of technical requirements to the ship characteristics. There is a possibility to regulate the feasible search space by enabling/ disabling of certain constraints.
The objective function or criterion optimization (1) represents the expected value of efficiency indexes [7]. This criterion seeks the maximization of expected (average) profit or the minimization of expected operational cost:

$$
\begin{gathered}
\mathrm{f}(\mathrm{X}, \mathrm{C})=\mathrm{M}\{\mathrm{EI}\} \text { Prob } \rightarrow \max \\
\mathrm{f}(\mathrm{X}, \mathrm{C})=\mathrm{M}\{\mathrm{EI}\}(1-\text { Prob }) \rightarrow \min
\end{gathered}
$$

where:

EI - efficiency indexes;

$\mathrm{M}\{\ldots\}$ - average.

The data of the problem assumes that the payoff (or cost) associated with each decision alternative is probabilistic.

Also there is a choice of another criterion form: aspiration level criterion, utility function.

In this formulation the optimization problem is usually nonlinear and conditionally divided into two parts. The first part deals with the ship mathematical model development, the second one provides the selection of the optimal solution search method.

These parts for each type of ship have their own peculiarities that effect the whole process of the problem solution. Particularly for SWATH ship it is possible to point further features.

The first SWATH ship feature as an optimization object is the technical solutions variety used while creating in the part of principle project and constructive layouts and their possible combinations. The studies gave an opportunity to reveal the significant changes in the relationship nature between the main structural elements of SWATH ship and well-known monohull ship. For example, the twin hull construction means the increasing of the dependence of the design characteristics on the size and configuration of the hulls and struts, much changing of the external load effect nature (forces and moments that act in cross direction become the most important), the value changing of the total resistance components, and, as a result, the constructive measures for its decrease. 
Possible relationship variants of the hull and strut sizes, shape parameters are so variable that while their proving it is necessary to make much research work. Even small changes of the hull form parameters while displacement increasing or decreasing influence the required propulsion power and the weight. The same way they influence the SWATH ship seakeeping performance. Thus, according to the study [5], for the pilot ship with a small waterplane area at the stage of preliminary design it was necessary to make 120 steps of design, each of them included the calculation of resistance and seakeeping control. Such number of variant elaborations can be done only with the help of special software. Besides, the hull shape, got by computer-aided design, must be adapted for the machinery layout and rudders.

The second SWATH ships feature is that the process of their optimal design is much complicated than in the traditional monohull ships and catamarans with simple hull configuration. It is known that all the performance of monohull ships are mainly defined by their principle dimensions (length, beam, draft and depth), block coefficient. To the catamarans with simple hull configuration the separation of demi-hulls and vertical clearance (Table 2) are added. And in case of SWATH ship it is important to consider the geometrical characteristics and shape parameters not only of each single hull, but also the struts, and, in addition, hydrodynamic interference effect of hulls and struts (Fig. 1) [2].

Besides, when designing SWATH ship it is important to consider the fact that external forces are defined not only by the geometrical hull, strut and their connections characteristics but also their positional relationships.

Tab. 2. Number of design variables and combinations

\begin{tabular}{|c|c|c|c|c|c|c|c|}
\hline Ship type & $\mathbf{L}$ & $\mathbf{B}$ & $\mathbf{D}$ & $\mathbf{d}$ & $\mathbf{C}_{\mathbf{b}}$ & $\begin{array}{c}\text { Number } \\
\text { of } \\
\text { variables }\end{array}$ & $\begin{array}{c}\text { Number of } \\
\text { combinations }\end{array}$ \\
\hline Monohull & 1 & 1 & 1 & 1 & 1 & 5 & $3^{5}=243$ \\
\hline Catamaran & 1 & 3 & 2 & 1 & 1 & 8 & $3^{8}=6561$ \\
\hline SWATH & 3 & 4 & 3 & 1 & 1 & 12 & $3^{12}=531441$ \\
\hline
\end{tabular}

The next feature is the lack of sufficient design and construction experience, and a small amount of built ships which can be used as the prototypes. Nowadays approximately 80 ships are built, and only 20 of them are for passengers.

While the SWATH ship project design there should be a justification of those characteristics that are not included into the design task, but at the same time have strong influence on the SWATH ship efficiency, notably:

- the selection of constructive and arranging type: mono, catamaran, trimaran, and other variants, number of struts; the selection of constructive materials with an opportunity to combine variants that are different for the hull and superstructure: steel, aluminum, glass-reinforced plastic;

justification of the spectrum of the comfort level with the arranging the passengers according to the categories, as well as according to the decks and cabins along the length of the ship;

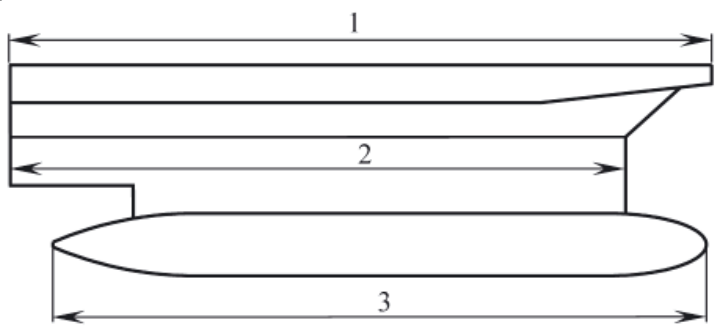

Fig. 1. SWATH ship design variables scheme
- justification of the spectrum of the cruising range and seakeeping levels in combination with the maximal and operational speed.

The development of the general arrangement of the ship also needs special attention because great area of the SWATH ship decks provides completely new ship space structure and presents almost unlimited possibilities in the inhabited area organization.

When solving the optimization problem there should be considered the existence and trustworthiness of the initial economical information used when estimating the ship efficiency. It is very difficult at the initial design stage to set the price of fuel, crew expenditures, port charges etc. These characteristics change during a season, not mentioning the operation time of 15-25 years. That's why consideration of the economic situation instability is rational to carry out by moving to the stochastic formulation of the optimization problem.

According to the information above there was developed a program complex (PC) SWATH Ship in order to find the best elements of the ship.

The basis of the PC mathematical support consists of the mathematical model of the ship as an engineering building and operational model.

\section{Mathematical model of SWATH ship}

The SWATH ship mathematical model contains analytical dependences that allow to define (Fig. 2): geometrical ship characteristics; lightship weight and deadweight; capacity (required areas for passengers and areas of service, public and sanitary rooms); intact stability and the stability (GZ) curve; geometrical characteristics of the fins; ship seakeeping performances; building cost.

The mathematical model is realized into two units: «SWATH model» and «Resist».

The «SWATH_model» unit contains the algorithm for calculation the basic SWATH ship characteristics.

The initial data for calculation are the start values of the independent variables, the parameters noted in the design task and extra data.

The selection of the main dimensions begins with the calculation of the ship payload:

$$
\mathrm{W}_{\mathrm{p}}=\left(\mathrm{P}_{\text {Pas }}+\mathrm{N}_{\text {Endr }} \cdot \mathrm{P}_{\text {Fr.w }}+\mathrm{P}_{\text {Prov }}\right) \cdot \mathrm{N}_{\text {Pas }} / 1000 ;[\mathrm{t}]
$$

where:

$\mathrm{P}_{\text {Pas }}$ - one passenger mass, [kg];

$\mathrm{P}_{\text {Fr.w }}-$ fresh water for a passenger per day, $[\mathrm{kg}]$;

$\mathrm{P}_{\text {Prov }}-$ provision for a passenger per day, $[\mathrm{kg}]$;

$\mathrm{N}_{\text {Pas }}-$ number of passengers;

$\mathrm{N}_{\text {Endr }}$ - endurance, [day].

Then the ship design displacement is estimated:

$$
\Delta=\mathrm{W}_{\mathrm{P}} / \eta_{\mathrm{P}} ;[\mathrm{t}]
$$

where:

$\eta_{\mathrm{P}}-$ payload coefficient.
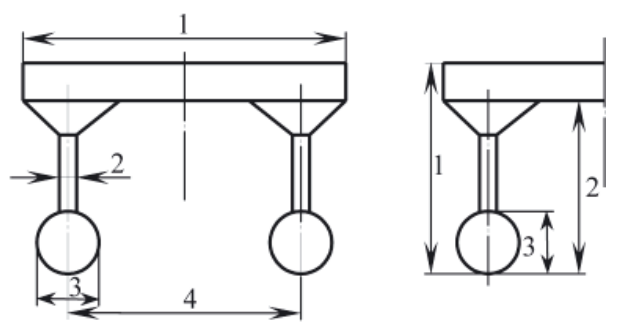


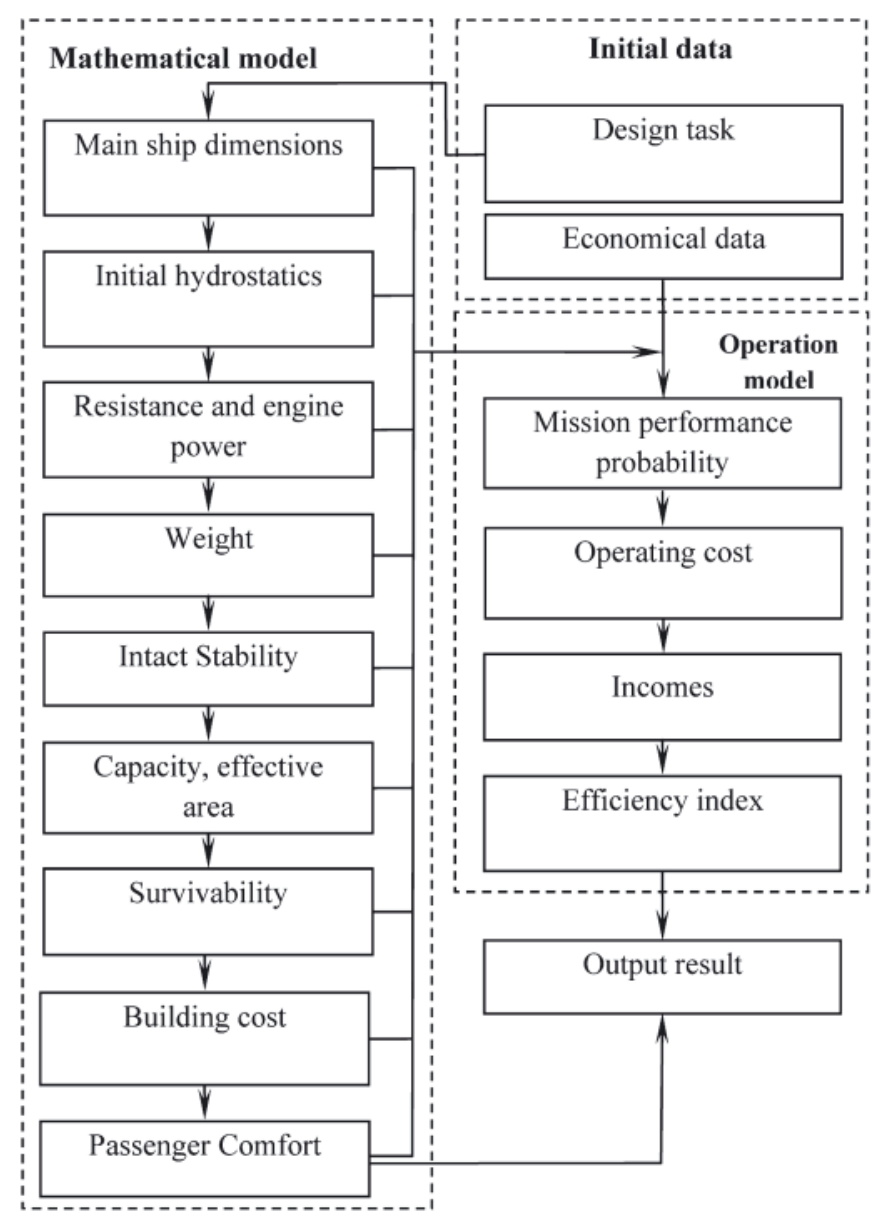

Fig. 2. Block diagram of the SWATH ship mathematical model and operational model

At the next stage the calculation of the basic SWATH ship geometrical characteristics is performed. Some of dependences are listed in the Table 3.

The formulas shown in Table 3 are obtained under the assumption that the lower hull forebody is elliptical, the stern is parabolic, the strut nose and tail are parabolic.

The values of the geometric SWATH ship characteristics are used to generate the hull surface, as well as to calculate the propulsive performance of the ship, weight and seakeeping.

Determination of the lightship weight and deadweight mass is performed by solving the weight equation:

$$
\Delta=\mathrm{W}_{\mathrm{LS}}+\mathrm{DW}
$$

where:

$\mathrm{W}_{\mathrm{LS}}$ - lightship weight, $\mathrm{t}$

DW - deadweight, t.

At the early stage of design the calculation of the SWATH ship lightship weight is reasonable to perform in the following groups:

$$
\mathrm{W}_{\mathrm{LS}}=\mathrm{W}_{\text {Hull }}+\mathrm{W}_{\text {Sup }}+\mathrm{W}_{\mathrm{M}}+\mathrm{W}_{\text {Out }}+\mathrm{W}_{\mathrm{SM}}
$$

where:

$\mathrm{W}_{\text {Hull }}$ - hull weight, [t];

$\mathrm{W}_{\text {Sup }}$ - superstructure weight, $[\mathrm{t}]$;

$\mathrm{W}_{\mathrm{M}}-$ machinery weight, [t];

$\mathrm{W}_{\text {Out }}$ - outfit weight, [t];

$\mathrm{W}_{\mathrm{SM}}-$ design margin, $[\mathrm{t}]$.

The biggest difficulty in calculation is the hull weight because of the lack of information about the prototype weight and statistic dependences. In PC in order to define the hull weight there was taken a basic approach. According to this approach [2] SWATH ship hull weight is estimated through the structural part thickness taking to account the operation load and requirements of the Ship-Classification Society:

$$
\mathrm{W}_{\text {Hull }}=\left(1+\mathrm{C}_{0}\right) \sum_{\mathrm{i}}\left(1+\mathrm{C}_{\mathrm{i}}\right) \mathrm{W}_{\mathrm{si}}
$$

where:

$\mathrm{C}_{0}=0.085$ - coefficient that takes into account the weight of additional components (painting, welding material and margin);

$\mathrm{C}_{\mathrm{i}} \quad-$ coefficient that takes into account the weight of other than the plate (stiffeners);

$\mathrm{W}_{\mathrm{si}} \quad-$ plate weight of the main SWATH ship structural part: lower hulls, struts, sponsons, box, inside decks and platforms, longitudinal and transverse bulkheads.

The plate weight of the SWATH ship hull structural parts is defined according to the following dependence:

$$
\mathrm{W}_{\mathrm{si}}=0.001 \sum_{\mathrm{i}=1}^{\mathrm{n}} \mathrm{S}_{\mathrm{i}} \mathrm{t}_{\mathrm{i}} \mathrm{q}_{\mathrm{i}} ;[\mathrm{t}]
$$

where:

$\mathrm{S}_{\mathrm{i}}, \mathrm{t}_{\mathrm{i}}, \mathrm{q}_{\mathrm{i}}-\operatorname{area}\left[\mathrm{m}^{2}\right]$, thickness [m] and density of the material $\left[\mathrm{kg} / \mathrm{m}^{3}\right]$ of the i hull part appropriately.

The surface area $\mathrm{S}_{\mathrm{i}}$ of the structural parts of the SWATH hull is determined using the parametrical model and is directly connected with independent variables.

For the ships with glass-reinforced plastic hulls the similar coefficients are difficult to obtain. That's why according to the calculations for several small waterplane area twin hull ships made of glass-reinforced plastic there was obtained the following dependence between the hull weight and ship displacement:

$$
\mathrm{W}_{\text {hull }}=0.2168 \Delta+4.6129
$$

The superstructure at the first approximation is calculated depending on the material by the formula:

$$
\mathrm{W}_{\mathrm{Str}}=\mathrm{g}_{\mathrm{Str}} \mathrm{V}_{\text {Sup }} ;[\mathrm{t}]
$$

where:

$\mathrm{g}_{\text {Str }} \quad-$ the superstructure volume density, $\left[\mathrm{t} / \mathrm{m}^{3}\right]$;

$\mathrm{V}_{\text {Sup }}$ - the superstructure volume with regard for the wheelhouse, $\left[\mathrm{m}^{3}\right]$.

The other lightship weight groups with some changing and improvements are defined by formulas that are used at the designing of the high speed passenger catamarans.

Providing of the passenger SWATH ship capacity is performed by calculating necessary areas:

$$
\mathrm{A}_{\Sigma}=\sum_{\mathrm{i}=1}^{\mathrm{n}} \mathrm{A}_{\mathrm{r}_{\mathrm{i}}} ;\left[\mathrm{m}^{2}\right]
$$

where:

$\mathrm{A}_{\mathrm{r}_{\mathrm{i}}}-$ required room area, $\left[\mathrm{m}^{2}\right]$;

$n-$ number of rooms on the ship.

When calculating the cost of ship building at the initial stage design the following expression was used:

$$
\mathrm{C}_{\mathrm{S}}=\left(1+\mathrm{k}_{1}\right)\left(\mathrm{C}_{\mathrm{M}}+\mathrm{C}_{\mathrm{O}}+\mathrm{C}_{\mathrm{W}}\right)
$$

where:

$\mathrm{k}_{1}$ - coefficient of the commercial expenditures and planned contributions, includes the value-added tax and the profit of the shipbuilding plant; 
Tab. 3. Calculation of the SWATH ship geometrical characteristics

\begin{tabular}{|c|c|c|}
\hline Item & Symbol & Formula \\
\hline Waterplane area, $\left[\mathrm{m}^{2}\right]$ & $\mathrm{A}_{\mathrm{WPS}}$ & $\mathrm{A}_{\mathrm{WPS}}=\nabla^{2 / 3} \mathrm{k}_{\mathrm{W}}$ \\
\hline Fore waterplane area coefficient of the strut & $\mathrm{C}_{\mathrm{WL}-\mathrm{F}}$ & $\mathrm{C}_{\mathrm{WL}_{-} \mathrm{F}}=\mathrm{n}_{\mathrm{s}} /\left(1+\mathrm{n}_{\mathrm{s}}\right)$ \\
\hline Aft waterplane area coefficient of the strut & $\mathrm{C}_{\mathrm{WL}-\mathrm{A}}$ & $\mathrm{C}_{\mathrm{WL}_{-} \mathrm{A}}=\mathrm{n}_{\mathrm{s}} /\left(1+\mathrm{n}_{\mathrm{s}}\right)$ \\
\hline Strut length, $[\mathrm{m}]$ & $\mathrm{L}_{\mathrm{S}}$ & $\mathrm{L}_{\mathrm{S}}=\sqrt{\frac{\mathrm{A}_{\mathrm{WPS}} \mathrm{I}_{\mathrm{S}}}{2 \mathrm{C}_{\mathrm{WPS}}}}$ \\
\hline Strut thickness, $[\mathrm{m}]$ & $\mathrm{t}_{\mathrm{S}}$ & $\mathrm{t}_{\mathrm{S}}=1_{\mathrm{S}} / \mathrm{L}_{\mathrm{S}}$ \\
\hline Midship section coefficient of the lower hull & $\mathrm{C}_{\mathrm{MH}}$ & $\mathrm{C}_{\mathrm{MH}}=\frac{\sqrt{\pi} \cdot \Gamma\left(\frac{1}{\mathrm{n}_{\mathrm{h}}}\right)}{2^{\frac{2}{\mathrm{n}_{\mathrm{h}}}} \cdot \mathrm{n}_{\mathrm{h}} \cdot \Gamma\left(\frac{1}{2}+\frac{1}{\mathrm{n}_{\mathrm{h}}}\right)}$ \\
\hline Block coefficient of the lower hull & $\mathrm{C}_{\mathrm{BH}}$ & $\mathrm{C}_{\mathrm{BH}}=\mathrm{C}_{\mathrm{MH}} \mathrm{C}_{\mathrm{PH}}$ \\
\hline Lower hull beam, $[\mathrm{m}]$ & $\mathrm{B}_{\mathrm{H}}$ & $\begin{array}{l}\text { from the equation solution } \\
\frac{2 \mathrm{C}_{\mathrm{BH}} 1_{\mathrm{H}} \mathrm{B}_{\mathrm{H}}^{3}}{\mathrm{~b}_{\mathrm{H}}^{3 / 2}}+\frac{\mathrm{A}_{\mathrm{WPS}}\left(\mathrm{l}_{\mathrm{d}}-1\right) \mathrm{B}_{\mathrm{H}}}{\mathrm{b}_{\mathrm{H}}}-\nabla=0\end{array}$ \\
\hline Lower hull depth, [m] & $\mathrm{H}_{\mathrm{H}}$ & $\mathrm{H}_{\mathrm{H}}=\mathrm{B}_{\mathrm{H}} / \mathrm{b}_{\mathrm{H}}$ \\
\hline Lower hull diameter, $[\mathrm{m}]$ & $\mathrm{D}_{\mathrm{H}}$ & $\mathrm{D}_{\mathrm{H}}=\sqrt{\mathrm{H}_{\mathrm{H}} \mathrm{B}_{\mathrm{H}}}$ \\
\hline Lower hull length & $\mathrm{L}_{\mathrm{H}}$ & $\mathrm{L}_{\mathrm{H}}=\mathrm{l}_{\mathrm{H}} \mathrm{D}_{\mathrm{H}}$ \\
\hline Ship draft, $[\mathrm{m}]$ & $\mathrm{d}$ & $\mathrm{d}=1_{\mathrm{d}} \mathrm{H}_{\mathrm{H}}$ \\
\hline Midship area of the lower hull, $\left[\mathrm{m}^{2}\right]$ & $\mathrm{A}_{\mathrm{MH}}$ & $\mathrm{A}_{\mathrm{MH}}=\mathrm{C}_{\mathrm{MH}} \mathrm{H}_{\mathrm{H}} \mathrm{B}_{\mathrm{H}}$ \\
\hline One lower hull displacement volume, $\left[\mathrm{m}^{3}\right]$ & $\nabla_{\mathrm{H}}$ & $\nabla_{\mathrm{H}}=\mathrm{C}_{\mathrm{PH}} \mathrm{A}_{\mathrm{MH}} \mathrm{L}_{\mathrm{H}}$ \\
\hline Strut submerged depth, $[\mathrm{m}]$ & $\mathrm{H}_{\mathrm{SS}}$ & $\mathrm{H}_{\mathrm{SS}}=\mathrm{d}-\mathrm{H}_{\mathrm{H}}$ \\
\hline Strut submerged volume, $\left[\mathrm{m}^{3}\right]$ & $\nabla_{\mathrm{S}}$ & $\nabla_{\mathrm{S}}=\left(\mathrm{A}_{\mathrm{WPS}} \mathrm{H}_{\mathrm{SS}}\right) / 2$ \\
\hline Strut setback, $[\mathrm{m}]$ & $\mathrm{S}_{\mathrm{b}}$ & $\mathrm{S}_{\mathrm{b}}=\mathrm{s}_{-} \mathrm{bL}_{\mathrm{H}}$ \\
\hline Length overall, $[\mathrm{m}]$ & $\mathrm{L}_{\mathrm{OA}}$ & $\mathrm{L}_{\mathrm{OA}}=\max \left(\mathrm{L}_{\mathrm{S}}+\mathrm{S}_{\mathrm{b}} ; \mathrm{L}_{\mathrm{H}}\right)$ \\
\hline Box length, $[\mathrm{m}]$ & $\mathrm{L}_{\text {Box }}$ & $\mathrm{L}_{\mathrm{Box}}=\min \left(\mathrm{L}_{\mathrm{S}}+\mathrm{S}_{\mathrm{b}} ; \mathrm{L}_{\mathrm{OA}}\right)$ \\
\hline Vertical (box) clearance, $[\mathrm{m}]$ & $\mathrm{H}_{\mathrm{DK}}$ & $\mathrm{H}_{\mathrm{DK}}=\max \left(0.75 \mathrm{~h}_{3 \%} ; 0.625 \sqrt{\mathrm{B}_{\mathrm{H}} \mathrm{H}_{\mathrm{H}}}\right)$ \\
\hline Strut depth, $[\mathrm{m}]$ & $\mathrm{h}_{\mathrm{S}}$ & $\mathrm{h}_{\mathrm{S}}=\mathrm{H}_{\mathrm{SS}}+\mathrm{H}_{\mathrm{DK}}$ \\
\hline Distance between lower hull center line, $[\mathrm{m}]$ & $\mathrm{B}_{\mathrm{S}}$ & $\mathrm{B}_{\mathrm{S}}=\mathrm{h}_{\mathrm{C}} \mathrm{L}_{\mathrm{H}}$ \\
\hline Box beam, $[\mathrm{m}]$ & $\mathrm{B}_{\mathrm{Box}}$ & $\mathrm{B}_{\mathrm{Box}}=\mathrm{B}_{\mathrm{S}}+\mathrm{B}_{\mathrm{H}}$ \\
\hline Depth of cross structure box, $[\mathrm{m}]$ & $\mathrm{H}_{\mathrm{DB}}$ & $\mathrm{H}_{\mathrm{DB}}=\left(\mathrm{B}_{\mathrm{Box}}-2 \mathrm{~B}_{\mathrm{H}}\right) / 7.5$ \\
\hline Depth up to the $[\mathrm{m}]$ ain deck, $[\mathrm{m}]$ & $\mathrm{D}$ & $\mathrm{D}=\mathrm{H}_{\mathrm{H}}+\mathrm{h}_{\mathrm{s}}+\mathrm{H}_{\mathrm{DB}}$ \\
\hline
\end{tabular}

$\mathrm{C}_{\mathrm{M}}-$ material cost, [US \$];

$\mathrm{C}_{\mathrm{O}}$ - equipment cost, [US \$];

$\mathrm{C}_{\mathrm{W}}-$ the labour cost, [US \$].

Cost of labour is calculated as follows:

$$
\mathrm{C}_{\mathrm{W}}=\left(1+\mathrm{k}_{\mathrm{O}}\right) \sum_{\mathrm{i}=1}^{\mathrm{N}} \mathrm{c}_{\mathrm{pi}} \mathrm{L}_{\mathrm{pi}}
$$

where:

$\mathrm{c}_{\mathrm{pi}}$ - unit hourly wage, [US \$/man-hours];

$\mathrm{L}_{\mathrm{Pi}}$ - labour man hours [8];

$\mathrm{N}$ - number of parts;

$\mathrm{k}_{\mathrm{O}}$ - coefficient that takes into account the overhead cost.
Hull material cost:

where:

$$
\mathrm{C}_{\mathrm{M}}=\left(1+\mathrm{k}_{2}\right) \sum_{\mathrm{i}=1}^{\mathrm{N}} \mathrm{c}_{\mathrm{i}} \mathrm{W}_{\mathrm{si}}
$$

$\mathrm{k}_{2}$ - coefficient that takes into account the material loses;

$c_{i}-$ specific is the cost of 1 ton material, [US $\$ / t$ ].

Equipment cost:

$$
\mathrm{C}_{\mathrm{O}}=\sum_{\mathrm{j}=1}^{\mathrm{K}} \mathrm{c}_{\mathrm{j}} \mathrm{W}_{\mathrm{j}}
$$

where:

$\mathrm{W}_{\mathrm{j}}-$ weight of unit, $[\mathrm{t}]$;

$c_{j}-$ cost of outfit per unit weight or power. 
The «Resist» unit implements the resistance calculation method $R_{T}$ and the propulsion engine power P. For defining the $R_{T}$ there was used the following formula:

$$
\mathrm{R}_{\mathrm{T}}=\mathrm{R}_{\mathrm{F}}+\mathrm{R}_{\mathrm{W}}+\mathrm{R}_{\mathrm{SP}}+\mathrm{R}_{\mathrm{AP}}+\mathrm{R}_{\mathrm{AA}}
$$

where:

$\mathrm{R}_{\mathrm{F}}, \mathrm{R}_{\mathrm{AB}}, \mathrm{R}_{\mathrm{AA}}$ - frictional, appendages and aerodynamic resistance;

$\mathrm{R}_{\mathrm{W}}, \mathrm{R}_{\mathrm{SP}} \quad$ - wave and spray resistance.

The calculation of frictional, appendages and aerodynamic resistance is performed by the known dependences of the ship theory considering the SWATH ship construction peculiarities $[3,9]$.

Spray resistance calculation is based on the results of the model tests, as described in [10].

The wave resistance of the small waterplane area twin hull ship is defined according to the formula, $\mathrm{kN}$ :

$$
\mathrm{R}_{\mathrm{W}}=\sum_{\mathrm{i}} \mathrm{R}_{\mathrm{Wi}}+\sum_{\mathrm{i}} \sum_{\mathrm{j}} \Delta \mathrm{R}_{\mathrm{Wij}}
$$

$\sum_{\mathrm{i}}^{\text {where: }} \mathrm{R}_{\mathrm{Wi}}$

- individual wave resistance of every body that is a part of the SWATH ship, [kN];

$\sum \sum \Delta \mathrm{R}_{\text {Wij }}$ - additional wave resistance as a result of the wave systems interference, [kN]. The wave resistance is defined for those bodies such as underwater hull, fore and aft struts. There is also an opportunity to calculate the resistance for the Slice type ships and single-hull SWATH ship.

In order to calculate the components of the SWATH ship wave resistance there was used the Michell integral:

$$
\mathrm{R}_{\mathrm{W}}=\frac{4 \rho g^{4}}{\pi \mathrm{U}^{6}} \int_{0}^{\pi / 2}\left(\mathrm{I}^{2}+\mathrm{J}^{2}\right) \mathrm{W}^{2} \sec ^{5} \theta \mathrm{d} \theta
$$

where:

$$
J(\theta)=-\int_{-\frac{L}{2}}^{\frac{L}{2}} \int_{-T}^{0} Y(x, z) \exp \left(k_{0} z \sec ^{2} \theta\right) \cos \left(k_{0} x \sec \theta\right) d x d z ;
$$$$
\theta \quad-\text { integration variable; }
$$

$\mathrm{k}_{0}=\mathrm{g} / \mathrm{U}^{2}-$ wave number, $[1 / \mathrm{M}]$;

$\mathrm{w}=2 \cos \left(\mathrm{k}_{0} \mathrm{bsec}^{2} \theta \sin \theta\right)$

$I(\theta)=-\int_{-\frac{L}{2}}^{\frac{L}{2}} \int_{-T}^{0} Y(x, z) \exp \left(k_{0} z \sec ^{2} \theta\right) \sin \left(k_{0} x \sec \theta\right) d x d z$;

$2 \mathrm{~b}-$ distance between center line of the hull, [m];

ń $\quad-$ fluid density, $\left[\mathrm{t} / \mathrm{m}^{3}\right]$;

$\mathrm{U} \quad-$ ship speed, $[\mathrm{m} / \mathrm{s}]$

$\mathrm{Y}(\mathrm{x}, \mathrm{z})$ - SWATH ship lower hull or strut offsets, $\mathrm{m}$. When calculating the wave integral, the original integration procedure according to the Filon rule was used.

Then the main engines power is defined:

$$
\mathrm{P}=\frac{\mathrm{P}_{\mathrm{E}}}{\eta_{\mathrm{S}} \eta_{\mathrm{D}}}(\mathrm{SM}+1),[\mathrm{kW}]
$$

where:

$$
\begin{array}{ll}
\eta_{\mathrm{s}} & - \text { propulsive coefficient; } \\
\mathrm{SM} & - \text { sea margin power; } \\
\mathrm{P}_{\mathrm{E}}=\mathrm{R}_{\mathrm{T}} \mathrm{U} & - \text { effective power, [kW]. }
\end{array}
$$

In the program there provided the power curve output or the output of the resistance curve, that visually show the dependence of total and other types of resistance from the ship speed.

\section{Operational problems}

The operational costs and the SWATH ship economic efficiency indexes are defined by the economic analysis in operational model. Operational model allows examining the ship dynamic operation being effected by chance factors. The chance factors under the environmental effect are generally defined by the hydrometeorological conditions, that typical for the examined operational area, as well as by the initial uncertain data, that are used in calculation of the operational economic indexes.

The operational model of the ship that makes regular scheduled cruises between two points is realized in the «Simulation» unit and contains three blocks: «Meteo», «Voyage», «Statistic». Before the ship setting out on a voyage there is a check of being ready to do that. In case of storm the ship voyage is canceled during the storm. Its value is generated in the «Meteo» block. In other cases the ship voyage between the departure point and destination is being modeled. While voyage there were calculated the coefficient of ship loading, the average cruise speed taking into account the wave height and wind speed, MSI and other operation indexes. In the port the passengers loading and unloading is being modeled. The process is repeated till the simulation time ends. Then the control is given to the «Statistic» block, where the statistic processing of the simulation results is performed and one of the economic efficiency indexes is calculated.

The program provides an opportunity to simulation the operation of one, two and three ships on the line according to the following shape of service: a ship that returns and doesn't return to the destination point on the same day; a ship that makes several trip per day; two or three ships that make series trip; two or three ships that make opposite trips. The voyages can be made every day or special days.

The economic analysis provides the calculation of one of chosen ship efficiency indexes: net present value (NPV), required freight rates (RFR), payback period (PP), net income (NI) and profitability index (PI).

The operation costs are defined as the sum of the following components:

$$
\mathrm{C}_{\mathrm{O}}=\mathrm{C}_{\mathrm{Fix}}+\mathrm{C}_{\mathrm{Var}}
$$

where:

$\mathrm{C}_{\text {Fix }}$ - fixed cost;

$\mathrm{C}_{\text {Var }}$ - voyage cost.

Fixed operation cost depends on the crew number, ship building cost and is calculated by:

$$
\mathrm{C}_{\text {Fix }}=\mathrm{C}_{\text {Crew }}+\mathrm{C}_{\mathrm{R}}+\mathrm{C}_{\mathrm{IS}}+\mathrm{C}_{\mathrm{D}}+\mathrm{C}_{\mathrm{Of}}
$$

where:

$\mathrm{C}_{\text {Crew }}$ - crew costs;

$\mathrm{C}_{\mathrm{R}}$ - repair and maintenance;

$\mathrm{C}_{\mathrm{IS}}$ - insurance;

$\mathrm{C}_{\mathrm{D}}$ - depreciation;

$\mathrm{C}_{\mathrm{Of}}$ - administration.

Voyage costs include the following components:

$$
\mathrm{C}_{\text {Var }}=\mathrm{C}_{\mathrm{P}}+\mathrm{C}_{\mathrm{F}}+\mathrm{C}_{\text {Oil }}
$$

where:

$\mathrm{C}_{\mathrm{P}}$ - port charges;

$\mathrm{C}_{\mathrm{F}}$ - fuel;

$\mathrm{C}_{\mathrm{Oil}}$ - lubrication oil. 
The SWATH ship economic efficiency analysis is performed with a glance of the risk factor and the factor of probability of the mission performance during the whole life cycle. For the passenger ships that perform scheduled voyages the probability of the mission performance can be estimated as following:

$$
\text { Prob }=\mathrm{P}_{1} \mathrm{P}_{2} \mathrm{P}_{3} \mathrm{P}_{4}
$$

where:

$\mathrm{P}_{1}$ - probability of the voyage performance;

$\mathrm{P}_{2}-$ probability of keeping the given average speed during the trip;

$\mathrm{P}_{3}-$ economic risks (probability of the nonnegative profit receiving);

$\mathrm{P}_{4}-$ reliability meaning the probability of the constructions and equipment accident - free operation.

The values of the probability of the mission performance and the parameters of the optimization criterion distribution law are defined via the simulation modeling of the ship trip elements.

The simulation modeling [11] is based on the computer reproduction of the extensive ship operation process with a glance of external environment interaction. The SWATH ship operation process is presented as serial manual of the ship operation process between the departure and destination point, load/unload it in ports, etc., taking into account the hydro- and meteorological conditions. As a result of such modeling certain events and conditions are fixed that allows to define the system efficiency characteristics.

The main stages of simulation modeling:

- Accumulation and statistical data manipulation in order to determine the distribution law;

- random numbers generation with given distribution laws using random numbers generators;

- construction and realization of the ship operation model;

- carrying out of the simulation experiment;

- statistical manipulation of the modeling results.

The block diagram of the simulation modeling procedure is shown in the Fig. 3.

The second part of the problem is solved with the optimization method depending on the design variables vector length, availability constraints, non-linear criterion and constraints. According to the analysis results the genetic

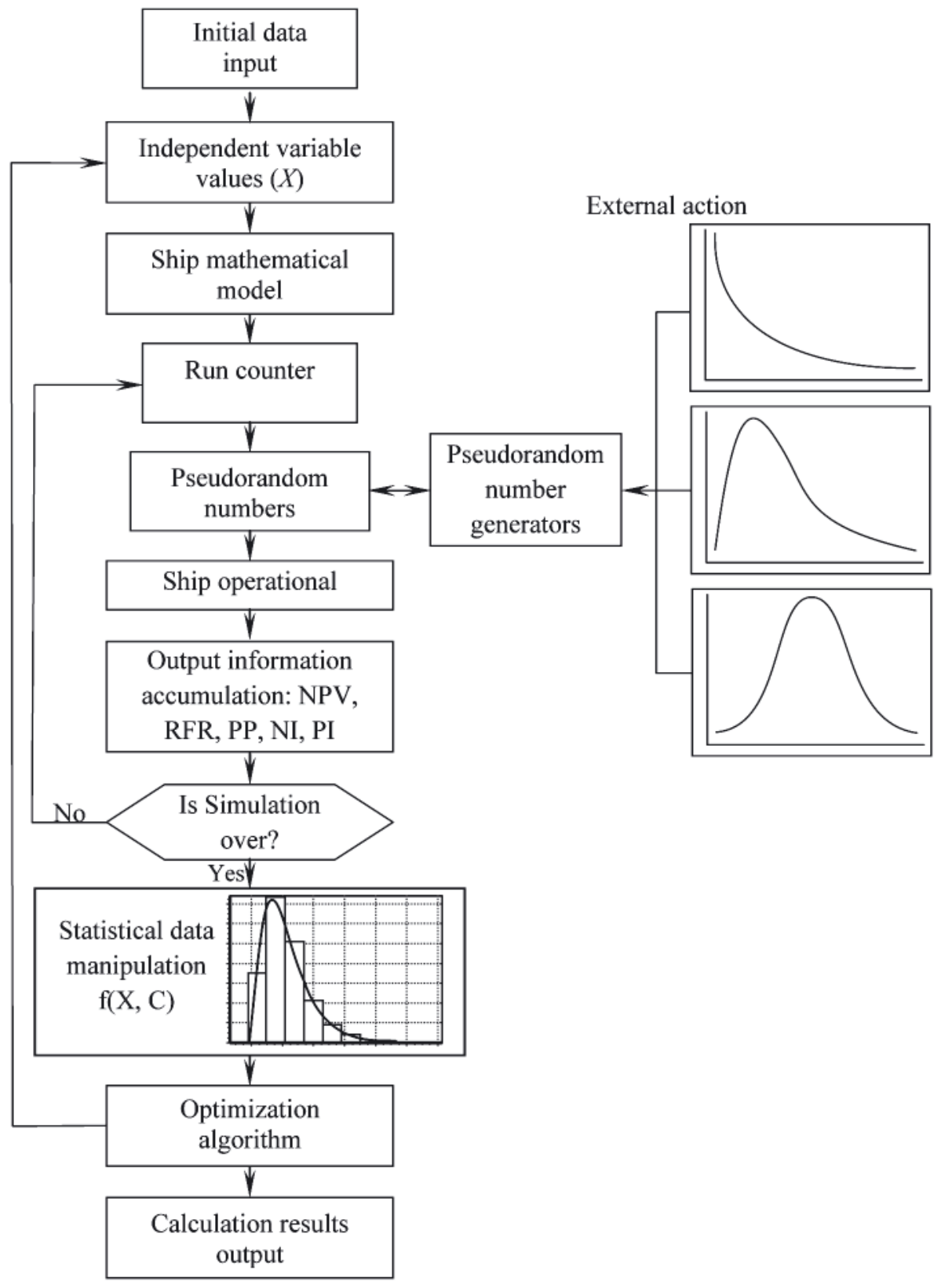

Fig. 3. Block diagram of the simulation modeling 
algorithm (GA) is suggested to use while solving the problem. GA is a simple evolution model in natural world that is realized as a computer program [12-14]. In the genetic algorithm, the analogues of natural genetics and natural selection are used. In general, the GA search strategy is described by the following cycle. At the first iteration the initial «population» is formed (the whole set of the project solutions). Then for each «individual» (problem solutions) the fitness function values are calculated, that helps to identify the best «individual». After that GA generates a new «population» with the genetic operators of selection, crossover, mutation and elitism strategy. For the new «population» the estimation of the fitness function value, etc. The process is repeated till one of the stopping criteria is performed.

The optimal solution search method with the application of genetic algorithm is realized in the «GeneticAlg» units.

Apart from the given units that realize the SWATH ship design methods, computer program contains the interface units that provide the operational comfort for the system user. The computer program interface allows to input the initial data, to choose the objective function type and economic efficiency indexes, to set the initial conditions of simulation, the parameters of the genetic algorithm and the determined and stochastic economic data, to output the calculation results in the graphical or tabular style.

The SWATH Ship program complex is designed in the Borland Delphi Professional 7.0 programing system and can be used in the Windows 98/XP/Vista operation systems.

The program complex can be used in the following range of characteristics: passenger carrying capacity $-20 \ldots 450$ persons; service speed $-20 \ldots 40$ knot; endurance $-100 \ldots 500$ miles; ship length $-20 \ldots 50 \mathrm{~m}$. Besides, using the SWATH Ship it's possible to carry out different experiments dealing with the check of the models validity, sensitivity etc.

\section{Results and verification}

In order to verify the calculations using the developed methodology and based on it programs complex, the series of the SWATH model towing tests (Fig. 4) were carried out in the towing tank of the National University of Shipbuilding.

The towing tests of the models were carried out at speeds of 0.5 to $3.0 \mathrm{~m} / \mathrm{s}$, that correspond to the Froude numbers in the length from 0.17 to 1.07 . The experiment was carried out in two stages. At the first stage the model with two struts on each hull was tested. After the first stage ended the space between the struts was sewn. And then the SWATH one-strut model was tested.

The results of the model testing were recalculated for the $32 \mathrm{~m}$ long full-size ship. Then with the help of the developed program the impedance values were obtained. Recalculation from the model to the full-size ship and the results of theoretical
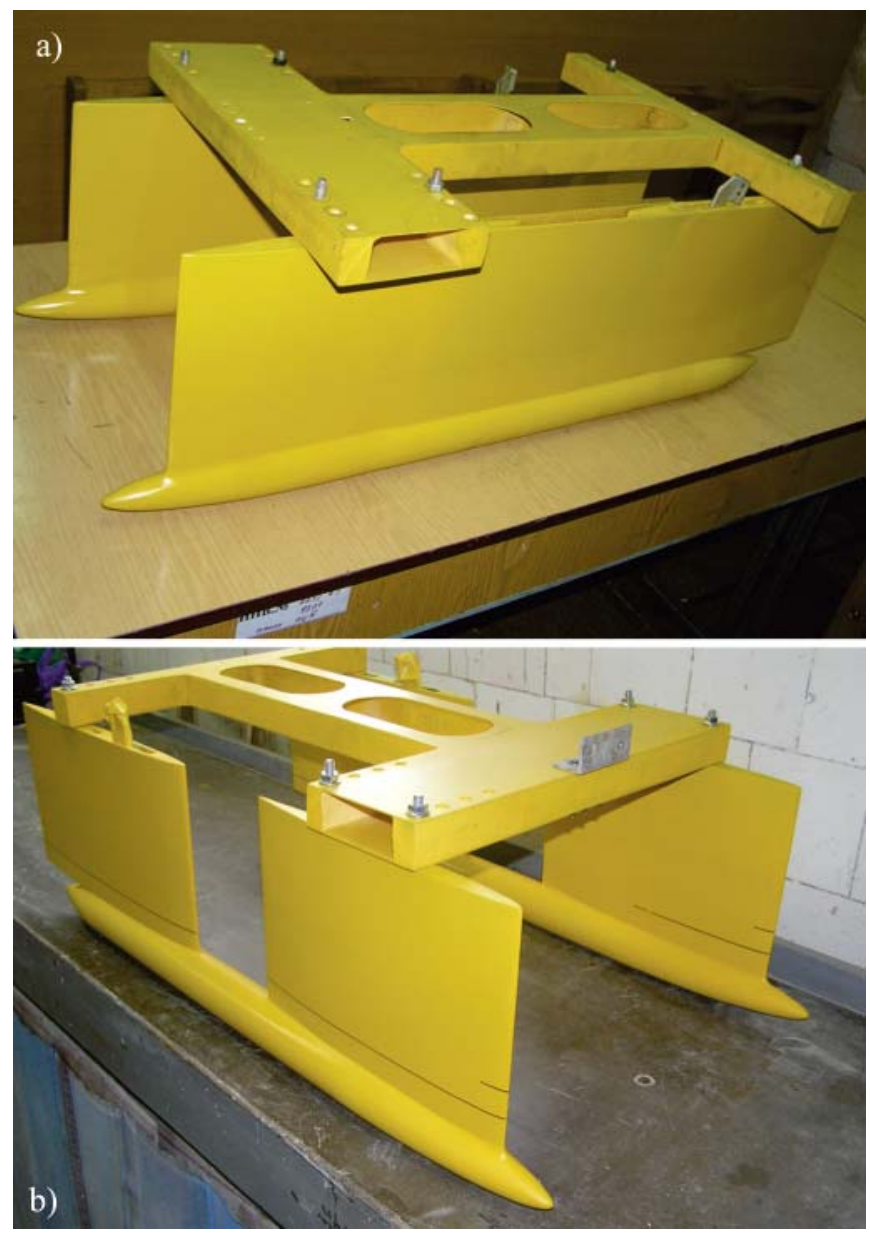

Fig. 4. SWATH models: $\boldsymbol{a})$ single strut; b) tandem strut

Tab. 4. Estimation of total ship resistance from model experiment and SWATH Ship program

\begin{tabular}{|c|c|c|c|c|}
\hline \multirow[b]{2}{*}{$\mathrm{U}_{\mathrm{M}},[\mathrm{m} / \mathrm{s}]$} & \multirow[b]{2}{*}{ Fr } & \multicolumn{2}{|c|}{$\mathbf{R}_{\mathrm{T}},[\mathrm{kN}]$} & \multirow[b]{2}{*}{ Error, $[\%]$} \\
\hline & & $\begin{array}{l}\text { from model } \\
\text { experiment }\end{array}$ & Theory by program & \\
\hline 0.625 & 0.2231 & 13.21 & 12.97 & 1.83 \\
\hline 0.875 & 0.3124 & 46.44 & 45.907 & 1.15 \\
\hline 0.882 & 0.3149 & 44.27 & 45.79 & 3.45 \\
\hline 1.000 & 0.3570 & 31.72 & 33.654 & 6.10 \\
\hline 1.250 & 0.4463 & 71.38 & 72.071 & 0.97 \\
\hline 1.500 & 0.5355 & 104.25 & 107.933 & 3.53 \\
\hline 1.750 & 0.6248 & 114.93 & 122.994 & 7.02 \\
\hline 2.000 & 0.7140 & 123.48 & 135.932 & 10.08 \\
\hline 2.25 & 0.8033 & 148.03 & 151.919 & 2.63 \\
\hline 2.5 & 0.8926 & 173.12 & 172.172 & 0.55 \\
\hline 2.75 & 0.9818 & 209.78 & 197.94 & 5.64 \\
\hline
\end{tabular}


a) $\mathrm{R}$

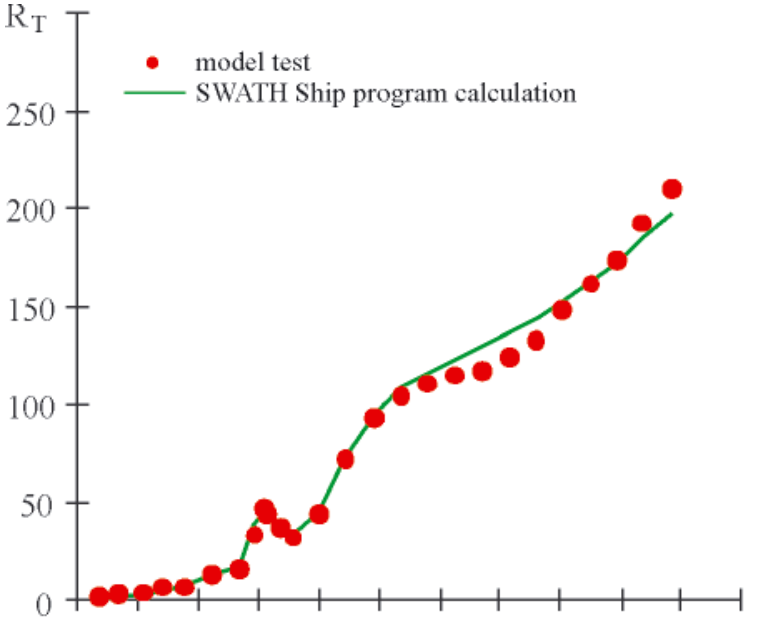

b)

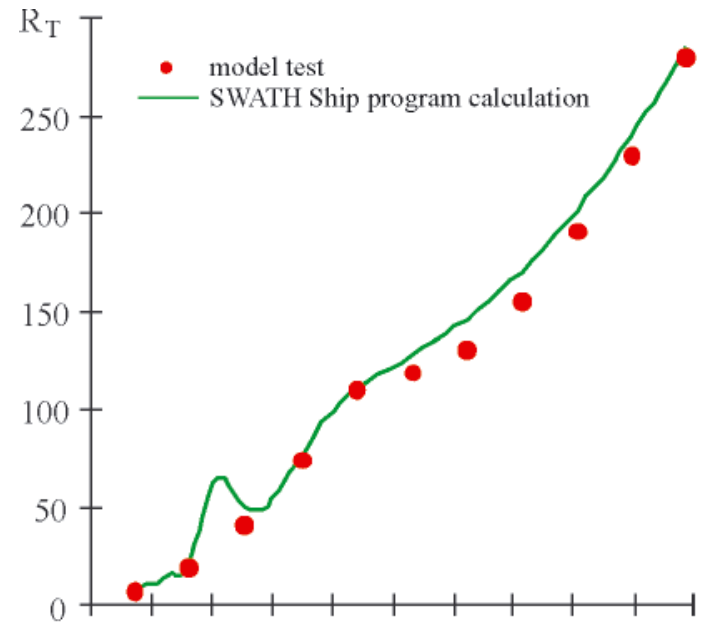

$\begin{array}{lllllllllllll}0.1 & 0.2 & 0.3 & 0.4 & 0.5 & 0.6 & 0.7 & 0.8 & 0.9 & 1.0 & \mathrm{Fr}\end{array}$

Fig. 5. Comparison of measured and calculated total ship resistance: a) Single strut SWATH ship, b) Tandem strut SWATH ship

Tab. 5. The SWATH optimal performance for the Odessa - Varna route

\begin{tabular}{|c|c|c|c|}
\hline \multirow{2}{*}{ Description } & \multicolumn{3}{|c|}{ Hull/Superstructure material } \\
\hline & Steel /Steel & $\begin{array}{l}\text { Aluminum Alloy } \\
\text { /Aluminum Alloy }\end{array}$ & $\begin{array}{c}\text { Steel } \\
\text { /Aluminum Alloy }\end{array}$ \\
\hline Lower hull length, [m] & 25.755 & 25.123 & 25.808 \\
\hline Lower hull beam, $[\mathrm{m}]$ & 2.472 & 1.786 & 2.295 \\
\hline Lower hull depth, [m] & 1.9 & 1.635 & 1.928 \\
\hline Hull nose length, [m] & 3.863 & 3.768 & 3.871 \\
\hline Hull tail length, [m] & 3.963 & 9.731 & 5.887 \\
\hline Strut length, $[\mathrm{m}]$ & 26.024 & 20.888 & 23.734 \\
\hline Strut thickness, $[\mathrm{m}]$ & 1.156 & 1.049 & 0.973 \\
\hline Strut height, $[\mathrm{m}]$ & 2.885 & 2.752 & 2.817 \\
\hline Strut nose length, $[\mathrm{m}]$ & 6.506 & 5.222 & 5.934 \\
\hline Strut tail length, $[\mathrm{m}]$ & 10.852 & 6.672 & 8.994 \\
\hline Waterplane area strut coefficient & 0.849 & 0.873 & 0.853 \\
\hline Box clearance, $[\mathrm{m}]$ & 2.092 & 1.743 & 2.005 \\
\hline Distance between lower hull center line, $[\mathrm{m}]$ & 10.507 & 9.628 & 10.328 \\
\hline Ship draft, $[\mathrm{m}]$ & 2.693 & 2.643 & 2.740 \\
\hline Depth up to the $[\mathrm{m}]$ ain deck, $[\mathrm{m}]$ & 5.79 & 5.367 & 5.749 \\
\hline Length overall, $[\mathrm{m}]$ & 26.378 & 25.123 & 25.808 \\
\hline Box length, $[\mathrm{m}]$ & 26.378 & 25.123 & 25.808 \\
\hline Box beam, $[\mathrm{m}]$ & 12.979 & 11.413 & 12.623 \\
\hline Depth of cross structure box, $[\mathrm{m}]$ & 1.004 & 0.98 & 1.004 \\
\hline Displacement, [t] & 250 & 150 & 225 \\
\hline Deadweight, $[\mathrm{t}]$ & 39.26 & 34.75 & 37.95 \\
\hline Main Engines, [number $\times \mathrm{kW}]$ & $2 \times 3460$ & $2 \times 2300$ & $2 \times 3460$ \\
\hline Generator, [kW] & 190 & 190 & 190 \\
\hline Crew & 5 & 5 & 5 \\
\hline Cost of ship, thousand [US \$] & 4857 & 3752 & 4767 \\
\hline Payback period, [year] & 9.3 & 5.9 & 8.4 \\
\hline Net Present Value, thousand [US \$] & 2390 & 4357 & 2427 \\
\hline
\end{tabular}


calculation of the one-strut SWATH towing resistance are shorn in the Table 4. Similar results were obtained for the two-strut SWATH.

According to the tests and calculated data using the developed program, the diagrams of the towing resistance and Floude number dependence for the one- (Fig. 5a) and two- strut (Fig. 5b) SWATH were constructed.

The results, obtained with the help of theoretical calculation using the developed program, quite accurately match the test data of the small size models.

The technique's working efficiency is shown by the example of solving the problem of choosing the best performance of the passenger SWATH for the Odessa - Varna route. The time schedule of the Krymskaya Strela catamaran is used in the calculation. During the calculating of capital investment in the ship construction it is supposed that the buyer's own funds are $20 \%$, and the rest $80 \%$ of investment is the bank loan for 8 years under the $6 \ldots 10 \%$ interest rate per year. The ship operational lifetime is 15 years. The net present value is used as an economical efficiency factor. The SWATH optimal performance values for the passenger Odessa - Varna shipping, obtained after the work of optimization program, are listed in the Table 5.

In order to define the main SWATH characteristics the genetic algorithm with the following parameters was used as an optimization method: population number -50 chromosomes, gene capacity -32 bit, crossover probability - 0.9, mutation probability -0.1 , inversion probability -0.05 , initial penalty -0.5 , extreme achieving accuracy -0.000001 . The elitism strategy was used during the optimization. These parameters are set experimentally as a result of multiple test runs of the program.
The calculation results have shown that the most economically efficient SWATH model is the one that is made of aluminum because it brings the highest return at the lowest expenditures and has less payback period.

\section{CONCLUSIONS}

1. The SWATH ship is more complicated for the optimization research than the conventional monohull ships and catamarans with traditional hull shape. First of all it's connected with the variability of the used technical solutions in the project and construction arrangement and their possible combinations. It's also connected with the difficult optimization process and lack of design and construction experience.

2. The general problem statement of the SWATH ship optimal design is characterized such complexity factors as large number of independent variables, presence of constraints, necessity to account the stochastic and uncertainty external agencies. The solving process of such problem provides the use of the penalty function approach (for the constraints account), genetic algorithm (for the direct optimum search) and simulation modeling (for the accounting of the data uncertainty).

Further research work is advisable to direct for improvement of the algorithm calculation of the propulsive coefficient, seakeeping performance and for enlargement of the model for other types of small waterplane area twin hull ship.

\section{Appendix A}
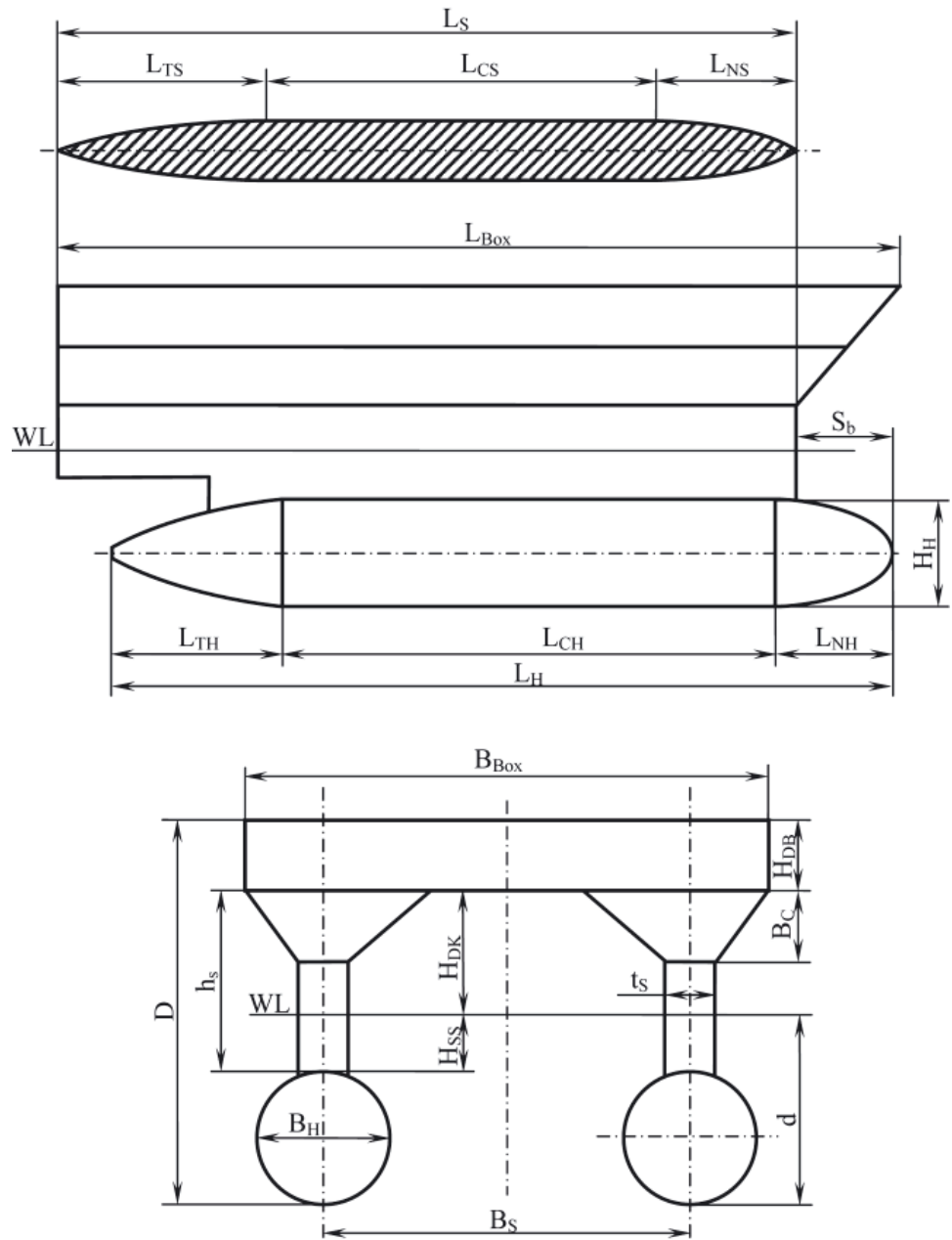

Fig. A.1. Hull form parameters 


\section{NOMENCLATURE}

A$$
\mathrm{A}_{\mathrm{r}_{\mathrm{i}}}
$$

$\mathrm{A}_{\text {WPS }}$

$\mathrm{b}_{\mathrm{H}}$

B

$\mathrm{B}_{\mathrm{Box}}$

$\mathrm{B}_{\mathrm{H}}$

$\mathrm{B}_{\mathrm{S}}$

C

$\mathrm{C}_{\mathrm{B}}$

$\mathrm{C}_{\mathrm{BH}}$

$\mathrm{C}_{\text {Crew }}$

$\mathrm{C}_{\mathrm{D}}$

$\mathrm{C}_{\mathrm{F}}$

$\mathrm{C}_{\mathrm{Fix}}$

$\mathrm{C}_{\mathrm{i}}$

$\mathrm{C}_{\mathrm{IS}}$

$\mathrm{C}_{\mathrm{M}}$

$\mathrm{C}_{\mathrm{MH}}$

$\mathrm{C}_{\mathrm{O}}$

$\mathrm{C}_{\text {Of }}$

$\mathrm{C}_{\text {Oil }}$

$\mathrm{C}_{\mathrm{p}}$

$\mathrm{C}_{\mathrm{PH}}$

$\mathrm{C}_{\mathrm{R}}$

$\mathrm{C}_{\mathrm{S}}$

$\mathrm{C}_{\mathrm{Var}}$

$\mathrm{C}_{\mathrm{WL}-\mathrm{A}}$

$\mathrm{C}_{\mathrm{WL}_{-} \mathrm{F}}$

$\mathrm{C}_{\mathrm{WPS}}$

$\mathrm{C}_{0}$

d

$\mathrm{D}_{\mathrm{H}}$

$\mathrm{D}_{\mathrm{W}}$

$\mathrm{f}(\mathrm{X}, \mathrm{C})$

Fr

$\mathrm{g}_{\mathrm{j}}(\mathrm{X})$

$\mathrm{g}_{\mathrm{Str}}$

$\mathrm{h}_{\mathrm{c}}$

$\mathrm{h}_{\mathrm{S}}$

$\mathrm{h}_{3 \%}$

$\mathrm{H}_{\mathrm{DB}}$

$\mathrm{H}_{\mathrm{DK}}$

$\mathrm{H}_{\mathrm{H}}$

$\mathrm{H}_{\mathrm{SS}}$

$\mathrm{k}_{\mathrm{W}}$

$\mathrm{k}_{0}$

$\mathrm{k}_{1}$

$1_{d}$

$1_{\mathrm{H}}$

$1_{\mathrm{NH}}$

$1_{\mathrm{NS}}$

$1_{\mathrm{S}}$

L

$\mathrm{L}_{\mathrm{OA}}$

$\mathrm{L}_{\mathrm{Box}}$

$\mathrm{L}_{\mathrm{H}}$

$\mathrm{L}_{\mathrm{S}}$

MSI

$\mathrm{n}_{\mathrm{a}}$

$\mathrm{n}_{\mathrm{f}}$

$\mathrm{n}_{\mathrm{h}}$ midship area of the lower hull, $\left[\mathrm{m}^{2}\right]$

required room area, $\left[\mathrm{m}^{2}\right]$

waterplane area, $\left[\mathrm{m}^{2}\right]$

ratio of the lower hull beam to its depth

breadth of the ship, [m]

box beam, [m]

lower hull beam, $[\mathrm{m}]$

distance between lower hull center line, [m]

vector of technical task

block coefficient

block coefficient of the lower hull

crew costs, [US \$]

depreciation cost, [US \$]

fuel cost, [US \$]

fixed cost, [US \$]

coefficient that takes into account the weight of

other than the plate

insurance cost, [US \$]

material cost, [US \$]

midship section coefficient of the lower hull

equipment cost, [US \$]

administration cost, [US \$]

lubrication oil cost, [US \$]

cost of port charges, [US \$]

lower hull prismatic coefficient

repair and maintenance cost, [US \$]

cost of ship, [US \$]

voyage cost, [US \$]

the cost of the work of the shipbuilding plant, [US \$]

aft waterplane area coefficient of the strut

fore waterplane area coefficient of the strut

waterplane area strut coefficient

coefficient that takes into account the weight of additional components (painting, welding material and margin)

- ship draft, [m]

- depth up to the main deck, [m]

- lower hull diameter, [m]

deadweight, [t]

efficiency criterion

Froude number

- ship performance requirements

- the superstructure volume density, [t/m $\left.\mathrm{m}^{3}\right]$

- ratio of the distance between lower hull center-

line to the length of the ship

strut depth, [m]

wave height of $3 \%$ probability

depth of cross structure box, $[\mathrm{m}]$

vertical (box) clearance, $[\mathrm{m}]$

lower hull depth, [m]

strut submerged depth, [m]

relative waterplane area

wave number, $[1 / \mathrm{M}]$

coefficient of the commercial expenditures and planned contributions, includes the value-added tax and the profit of the shipbuilding plant

- ratio of the ship draft to the lower hull diameter relative length of lower hull

hull nose length to lower hull ratio

strut nose length to strut length ratio

slenderness coefficient of strut

length of the ship, [m]

length overall, [m]

box length, $[\mathrm{m}]$

lower hull length, $[\mathrm{m}]$

strut length, [m]

motion sickness indexes

factor of the lower hull tail shape

factor of the lower hull nose shape

factor of the lower hull cross section shape n

$\mathrm{N}_{\mathrm{Pa}}$

$\mathrm{N}_{\text {End }}$

$\mathrm{P}$

$\mathrm{P}_{\mathrm{E}}$

$P_{\text {Fr.w }}$

$\mathrm{P}_{\text {Pas }}$

Prob

$\mathrm{P}_{\text {Prov }}$

$\mathrm{P}_{1}$

$\mathrm{P}_{2}$

$\mathrm{P}_{3}$

$\mathrm{P}_{4}$

$\mathrm{q}_{\mathrm{i}}$

$\mathrm{R}_{\mathrm{AA}}$

$\mathrm{R}_{\mathrm{AP}}$

$\mathrm{R}_{\mathrm{F}}$

$\mathrm{R}_{\mathrm{SP}}$

$R_{T}$

$\mathrm{R}_{\mathrm{W}}$

$\mathrm{s} b$

$\mathrm{S}_{\mathrm{b}}$

$\mathrm{S}_{\mathrm{i}}$

SM

$t_{i}$

$t_{\mathrm{s}}$

$\mathrm{U}$

$\mathrm{V}_{\text {Sup }}$

$\mathrm{W}_{\text {Hull }}$

$\mathrm{W}_{\mathrm{LS}}$

$\mathrm{W}_{\text {Out }}$

$\mathrm{W}_{\mathrm{P}}$

$\mathrm{W}_{\mathrm{M}}$

$\mathrm{W}_{\mathrm{si}}$

$\mathrm{W}_{\mathrm{SM}}$

$\mathrm{W}_{\text {Sup }}$

$x_{i}^{\text {min }}$

$\mathrm{x}_{\mathrm{i}}^{\max }$

$\mathrm{X}$

$2 \mathrm{~b}$

$\Gamma$

$\Delta$

$\eta_{\mathrm{P}}$

$\eta_{\mathrm{s}}$

$\rho$

$\sum_{i} R_{W i}$

$\sum_{\mathrm{i}} \sum_{\mathrm{j}} \Delta \mathrm{R}_{\mathrm{Wij}}$

$\nabla$

$\nabla_{\mathrm{H}}$

$\nabla_{\mathrm{S}}$ strut nose and tail shape factor

number of passengers

endurance, [day]

engine power, $[\mathrm{kW}]$

effective power, [kW]

fresh water for a passenger per day, $[\mathrm{kg}]$

one passenger mass, $[\mathrm{kg}]$

probability of the mission performance

provision for a passenger per day, $[\mathrm{kg}]$

probability of the voyage performance

probability of keeping the given average speed during the trip

economic risks (probability of the nonnegative profit receiving)

reliability [m]eaning the probability of the constructions and equipment accident-free operation

density of the $[\mathrm{m}]$ aterial hull part $\left[\mathrm{kg} / \mathrm{m}^{3}\right]$

aerodynamic resistance, $[\mathrm{kN}]$

appendages resistance, $[\mathrm{kN}]$

frictional resistance, $[\mathrm{kN}]$

spray resistance, $[\mathrm{kN}]$

total resistance, $[\mathrm{kN}]$

wave resistance, $[\mathrm{kN}]$

strut setback

strut setback, [m]

area of the i hull part $\left[\mathrm{m}^{2}\right]$

sea margin power

thickness of hull part [m]

strut thickness, [m]

ship speed, $[\mathrm{m} / \mathrm{s}]$

model speed, $[\mathrm{m} / \mathrm{s}]$

superstructure volume, $\left[\mathrm{m}^{3}\right]$

hull weight, [t]

lightship weight, $[\mathrm{t}]$

outfit weight, [t]

payload, [t]

machinery weight, [t]

plate weight of the main SWATH ship structural part: lower hulls, struts, sponsons, box, inside

decks and platforms, longitudinal and transverse bulkheads

design margin, [t]

superstructure weight, $[\mathrm{t}]$

minimun value of independent variable

maximum value of independent variable

vector of independent variables

SWATH ship lower hull or strut offsets, [m]

distance between center line of the hull, $[\mathrm{m}]$

gamma-function

displacement, $[\mathrm{t}]$

payload coefficient

propulsive coefficient

fluid density, $\left[\mathrm{t} / \mathrm{m}^{3}\right]$

individual wave resistance of every body that is a part of the SWATH ship, $[\mathrm{kN}]$

additional wave resistance as a result of the wave systems interference, $[\mathrm{kN}]$

volume displacement, $\left[\mathrm{m}^{3}\right]$

one lower hull displacement volume, $\left[\mathrm{m}^{3}\right]$

strut submerged volume, $\left[\mathrm{m}^{3}\right]$

\section{REFERENCES}

1. Dubrovskiy, V. A.; Matveev, K.; Sutulo, S.: Small Waterplane Area Ships. Fair Lawn, Backbone Publishing Co., 2007.

2. Lee, K.Y.; Lee, D.K.; Kim, Y.D.: A Computer-Based Design Model for Coastal Passenger SWATH Ships. Journal of Ship Technology Research, № 2 (36), pp. 72-83, 1989.

3. Nethercote, W.C.; Scnmitke, R.T.: A Concept Exploration Model for SWATH Ships. The Naval Architect Journal, vol. 124, № 5 , pp. 113-130, 1982. 
4. Pal, P.K.: Computer-aided Design of Swath Passenger Ferries. Pacific 2006 International Maritime Conference. Sydney, pp. 460-469, 2006.

5. Spethmann, K.: A realised SWATH-Application as an Example for Naval Purposes. Jahrbuch der Schiffbautechnischen Gesellschaft. Band 95., pp. 213-221, 2001.

6. Tantsjura, A.G.: Mathematical model of a small waterplane area twin hull (SWATH) ship for optimization of its characteristics. Collected papers of NKI, Nikolaev, Vol. 154, pp. 44-53, 1979.

7. Taha, H.A.: Operations Research: An Introduction. Eighth Edition. New Jersey: Pearson Education, 2006.

8. Miroyannis, A.: Estimation of ship construction costs. Massachusetts Institute of Technology, 2006

9. Bertram, V.: SWATH Ship Design Formulae Based on Artificial Neural Nets. Journal of Ship Technology, vol. 3, № 1, pp. 1-9, 2007.

10.Chapman, R.B.: Spray drag of surface piercing struts. AIAA/ SNAME Advanced Vehicles Conference, Annapolis, july, 1972.

11.Law, A.M.; Kelton, W.D.: Simulation Modeling and Analysis. Third Edition. New York: McGraw-Hill, 2000.
12.Back, T.: Evolutionary Algorithms in Theory and Practice. New York: Oxford University Press, 1996.

13.Davis, L.: Handbook of Genetic Algorithms. New York: Van Nostrand, 1991.

14.Michalewicz, Z.: Genetic Algorithms + Data Structures $=$ Evolution Programs. Berlin-Heidelberg: Springer-Verlag, 1996.

\section{CONTACT WITH THE AUTHORS}

Oleksandr V. Bondarenko, Assoc. Prof. Anzhela P. Boiko, Assoc. Prof.

Iryna R. Seropyan, Engineer second class Admiral Makarov National University of Shipbuilding, Mykolayiv

Faculty of Naval Architecture

9 Geroi Stalingrada Ave, Mykolayiv, Ukraine, 54025

e-mail: Oleksandr.Bondarenko@nuos.edu.ua e-mail: Angboyko@mail.ru e-mail: Iryna.seropyan@nuos.edu.ua 